\title{
The Interface between Childcare, Family Support and Child Poverty Strategies Under New Labour: Tensions and Contradictions
}

\section{Eva Lloyd}

Cass School of Education, University of East London

E-mail: e.lloyd@uel.ac.uk

New Labour's national childcare and family support strategies have been aimed at improving mothers' labour market participation and children's future educational achievements. As such, they constitute a key component of the child poverty agenda. HM Treasury has assumed a pivotal role in furthering the strategies' objectives. This article explores whether the mixed market economy selected as the vehicle to deliver childcare and family support provision, promotes separate markets for the poor and the better off, while hindering the achievement of child poverty strategy outcomes.

\section{Introduction}

Writing shortly after the Labour Government first took office, Daniel and Ivatts (1998: 145) observed that:

no other aspect of the post-1945 UK welfare state has failed children so badly as its policy on early years education and care.

From 1997 a raft of Labour Manifesto proposals concerning the provision of early childhood education, childcare and family support provision, were swiftly translated into policy and strategic action plans addressing this fragmented field (DfEE, 1998). These were set out alongside other family policy proposals from the newly established Ministerial Group on the Family in a wide-ranging consultation document, Supporting Families (Home Office, 1998), ranging across five domains. The National Childcare Strategy (DfEE, 1998), was identified as a key factor in achieving the overall objectives of three domains: (1) better services and support for parents, including targeting disadvantaged areas through the Sure Start family support initiative, (2) better financial support for families through the tax and benefit system and (3) helping families balance work and family life by promoting family friendly working practices and increasing family-related employee rights. Supporting Families' primary focus was on developments in England, as it followed the ratification of four UK devolution acts, which enabled the devolved jurisdictions to lead these and other social welfare policy areas. ${ }^{1}$

With an explicit role in promoting mothers' employment and children's future educational achievements as a means of addressing child poverty, the National Childcare Strategy aimed to ensure universal access to quality and affordable childcare ${ }^{2}$ for children aged nought to 14 in every neighbourhood. As part of this strategy, New Labour introduced a universal entitlement to free early education for all three- and four-year old children, 
reflecting a 'public good' vision of education in general (OECD, 2006). The majority of four-year olds were already enrolled in reception classes of state primaries, though. Early education for the remaining four-year olds and three-year olds was to be provided within the mixed economy of statutory and private providers; the latter sector qualified for receiving the Early Education grant, provided a new early years curriculum was implemented (Duffy, 2006). Most free early education for three-year olds continued to be delivered by the for-profit and not-for-profit private sector (Butt et al., 2007). Eventually, the Children's Plan (DCSF, 2007) would extend this entitlement to certain disadvantaged two-year olds.

In contrast, a complex mix of short-term and tapering, supply-side subsidies to childcare and family support providers was introduced to encourage the development of wrap-around childcare services, early childcare for under threes and school-age childcare, while tax credits acted as a demand-side subsidy to help employed parents with registered childcare costs. The entire system of demand- and supply-side subsidies was intended to stimulate the childcare markets (Pugh, 2006: 12). To promote integrated early education and childcare provision nationwide and simplify the system for both children and parents, over one hundred integrated settings, many developed from maintained nursery schools, became designated 'Early Excellence' centres, intended as models of good practice.

Simultaneously, in 1998 the Treasury played a pivotal role in establishing the multiagency Sure Start initiative, a targeted programme for children aged three and under and their families living in disadvantaged areas. Designed to improve both children's quality of life and school readiness (Glass, 1999; Belsky et al., 2007) and informed by USA longitudinal research whose applicability to the UK situation is problematic (Penn et al., 2006), Sure Start delivered family support along community development lines with a great deal of parental involvement. Its mix of family provision included parenting education, drop-ins and crèches, family health provision and job advice, but not childcare. It clearly reflected the 'welfare model' of early childhood provision in targeting mothers in order to support their parenting (Penn, 2007: 196). This type of family support remained distinct from the package of support measures to help parents balance work and family life, which was subsequently developed by the Department of Work and Pensions (Lewis and Campbell, 2007).

Alongside Sure Start, the Neighbourhood Nurseries initiative, rolled out from 2000 in England, represented the first large-scale programme aimed at substantially expanding childcare provision in disadvantaged areas and demonstrating how integrated early education and childcare could be delivered through a mixed economy of private forprofit and not-for-profit and statutory providers (NAO, 2004; La Valle et al., 2007; Smith et al., 2007).

Right from the start, the Labour Government's childcare and family support strategies reflected a clear anti-poverty focus, both in their promotion of parental employment, especially that of mothers (Piachaud and Sutherland, 2001) and in their emphasis on improving children's educational performance (Gregg and Machin, 2001; Tomlinson, 2001). These policies were informed by economic and policy research in industrialised nations, suggesting that mothers' employment was central to creating a route out of poverty for children and their families (Solera, 2001; Vleminckx and Smeeding, 2001). These strategies became key to the emerging child poverty agenda (Lloyd, 2006), itself part of a wider anti-poverty agenda initiated by the Treasury (HM Treasury, 1999, 2001).

Rigby et al. (2007) draw attention to the longer-term social and political consequences of early childhood education and childcare policy designs selected by policy makers. 
Taking examples from a major OECD comparative study (OECD, 2001, 2006), they illustrate how policy formation institutionalises ethical and value-laden positions and dominant paradigms, which in turn influence subsequent social and policy debates. They conclude that:

What makes this process so critical is the institutional stickiness of policy designs, which makes it difficult to alter a course of action once a particular institutional arrangement has been adopted. (Rigby et al., 2007: 106)

The implications of New Labour's childcare policy decisions for their interface with the child poverty strategy were to emerge gradually. The extent and stark nature of child poverty and social exclusion in Britain in the late nineties had been extensively documented (Gordon and Pantazis, 1997, Middleton et al., 1997; Gordon et al., 2000). While spending on children increased (Sefton, 2004), its effectiveness would remain in doubt (Bradshaw and Mayhew, 2005; Harker, 2006).

Rather than as a response purely to national conditions, both New Labour's focus on child poverty ${ }^{3}$ and the high profile given to childcare and family support evolved against an international policy background, informed by European (Ruxton and Bennett, 2001) and global anti-poverty policy initiatives, such as the 1995 Copenhagen Summit. Labour inherited both the previous administration's commitment to overall poverty reduction, and its aspiration to realise the rights of British children under the 1989 United Nations Convention on the Rights of the Child, including their right to an adequate standard of living stipulated by Article 27 (UN, 1989).

New Labour's initial childcare strategy strongly reflected the views of US economist James Heckman on the impact of investment in the early years (Heckman, 2000), as well as the impact of the 1997 European Employment Strategy, which resulted in the 2000 Lisbon Declaration by European leaders. This committed the EU to becoming by 2010 the most dynamic and competitive knowledge-based economy in the world (EU High Level Group, 2004). During the nineties, the OECD's Education and Training Directorate (OECD, 2001) had undertaken a comparative and thematic review of 12 member states' early childhood systems. A substantial public investment in services and their infrastructure was identified as a key element of policy likely to promote equitable access to quality childcare provision for children as an entitlement in their own right.

Conveniently for Labour policymaking (Penn (2007: 193), these recommendations were later flatly contradicted by the OECD's Directorate for Employment, Labour and Social Affairs (OECD, 2003, 2005), who considered increasing maternal employment as the primary rationale for investment. Nevertheless, other OECD reports also emphasised the economic grounds for treating early childhood care and education as a 'public good' (Cleveland and Krashinsky, 2003) and thus avoid social stratification (Leseman, 2002). Subsequent UK developments proved at odds with the policy direction suggested in either category of OECD reports.

\section{Childcare, welfare reform and the Third Way}

At the level of national politics, New Labour's childcare and family support policies need to be located within the wider context of its welfare reform agenda. Driven by Third Way politics (Giddens, 1998, 2000), this emphasised the coupling of (welfare) rights with 
responsibilities; predictably, children's own position within the rights and responsibilities debate remained contested (Such and Walker, 2005). Such reforms, aimed at creating a sustainable welfare state, had a clearly defined dual purpose:

A revitalised welfare state has just two purposes - to move people into work or into new skills. The days of open-ended welfare need to end. (Latham, 2001: 27)

Again, Britain was not alone in pursuing this agenda. At the time, welfare state retrenchment and the increasing subordination of social policy goals to economic ones could be widely observed in democratic capitalist welfare states (Swank, 2005), although the incompatibility of economic competitiveness with high levels of welfare spending would continue to be questioned (Hay, 2005: 197).

Given this context, the question arises: how central were the issues around quality of life, education, welfare and optimal development of young children themselves within such policy developments? Reflecting on the first Labour administration, Hendrick (2003: 206) argues that Third Way thinking did acknowledge the actual and potential impact on children's welfare of the three major transformations in society: globalisation, the emergence of the knowledge economy and the changes to the structure and functioning of the family. However, children's place within the new society, their place within their communities and within their families, had not yet been worked through at the time of the first Labour administration (Hendrick, 2003: 209).

While acknowledging that the profile of young children and childcare had been raised early on in Labour's first term, Daniel and Ivatts (1998: 166) warned that:

any optimism that the current consensus will provide a new deal for young children must be tempered by the fact that the debate has ... been far from child-centred. Whether on the needs of working parents or the requirements of the economy for a skilled workforce, the debate has, in the main, been dominated by adult concerns.

This warning proved prescient. The principle of 'progressive universalism' (HM Treasury, 2001) shaped provision for the poor or those less able to compete in the employment market, presumably including children, i.e. some support for all from public funds, but most for those most in need of it. High priority was given to improving children's life chances and the pledge made to eliminate child poverty altogether by 2020 (Blair, 1999). However, as welfare policies evolved, rhetoric concerning citizens' rights and responsibilities still figured prominently (Brewer et al., 2002). Under New Labour the dominant discourse around child poverty was to remain in terms of potential loss of human capital (Hendrick, 2003: 212).

With New Labour's early childhood policies subservient to the aim of welfare reform, childcare and family support, like other health and welfare services, were delivered within a mixed economy of welfare (Powell, 2007; Stewart, 2007), underpinned by neo-liberal free market principles. The emphasis on the private-for-profit and the private-not-forprofit sector entering into service delivery partnerships with Government continued the trend set under the previous Conservative Government, although the marketisation and privatisation of childcare provision became even more pronounced after 1997 (Cohen et al., 2004; Penn, 2007). 
In this way, the UK consolidated its position among the Anglo-Saxon or liberal welfare regimes (Esping-Andersen, 1990, 1999), which:

emphasise targeted policies including means-tested benefits, and prioritise the market with government intervention in the case of acute market failure. (Moss et al., 2003: 6)

Only a summary of the wide and complex range of New Labour's early childhood and child poverty policies and strategies can be provided here, but in-depth discussions are available elsewhere (Cohen et al., 2004; Pugh and Duffy, 2006).

\section{Childcare and child poverty under New Labour: tensions and contradictions}

Even during its first term in office, New Labour's package of childcare and family support policies came in for some criticism from early years organisations, practitioners, managers, academics and policy analysts, primarily because of the complexities of their implementation and the burden placed on providers by the volume and short-term nature of childcare funding strategies. Penn (2007), though, considers that the majority of academics and advocates in the field of early years persistently ignored the implications for poor children of the political shift in Labour's thinking, which prioritised the economic benefits of women's labour market participation over the redistributive function of a universal, publicly funded and equitable system of early childhood education and care provision uncoupled from parental employment status.

Expansion of provision largely occurred among day nurseries for children under two (DfES, 2001). The interface between demand and supply side childcare subsidies was characterised by anomalies and caused problems for parents and providers (Lloyd, 2000). The universal free early education entitlement for three- and four-year old children covered only twelve and a half hours of provision weekly during term. Parents of children this age therefore needed 'wrap-around' childcare provision if they were to take any paid work. To qualify for childcare tax credits parents needed to work at least 16 hours. Moreover, modelling the economic impact of different formats of childcare subsidy, Duncan et al. (2001) concluded that they might influence parental choice and quality of provision without encouraging maternal employment. Eventually, the House of Commons Public Accounts Committee (House of Commons, 2007: 6) would highlight the persistent failure of the tax credit system.

Although the early education targets for three- and four-year olds were achieved, variable levels of childcare availability for children aged nought to 14, especially at atypical times, caused significant pressures for families (La Valle et al., 2002; Dex, 2003; Statham and Mooney, 2003). Research uncovered a variety of parental attitudes towards maternal employment and the use of formal childcare for very young children, and a preference for informal, and hence unregistered, childcare for this age group (La Valle et al., 2000; Woodland et al., 2002). In the changing policy environment, mothers continued to struggle to reconcile paid work and family life (Skinner, 2003), while entering paid work seriously complicated the daily lives of lone mothers and their children (Sutherland, 2002; Bell et al., 2005a).

Among policy analysts, Cohen et al. (2004: 195) claimed that a gulf remained between the principles underpinning childcare and early education services, although Smith (2007) would conclude that the first ten years of Labour had amounted to a 
quiet revolution in early childhood services. Moss $(1999,2001)$ regretted that Labour eschewed the opportunity to rethink the purpose of early childhood services and create a more coherent system of early childhood provision in favour of maintaining some of the problematic divisions by which it had previously been characterised. According to Penn and Randall (2005: 79) these problems not only reflected the:

constraining legacy of previous policy and provision, but must also be related to the way childcare has fitted into the wider government agenda, and 'Third Way' discourse.

Maintaining the split between publicly funded early education and a subsidised market in childcare for working parents and largely paid for by them, hindered poor children's access by preventing the development of an equitable and universal childcare system (Moss et al., 2000; Brannen and Moss, 2003).

The more disadvantaged children, who stood most to gain from good quality provision (Melhuish, 2004), particularly those from Black and minority ethnic families, were more likely to encounter segregated and lower quality provision, unless it was statutory (Sylva et al., 2004). Although the poorest parents in a UK study were keen on childcare for their children for social and educational, rather than primarily economic reasons, they often failed to access it (Ghate and Hazell, 2002).

Sure Start remained on target, as funding had been earmarked for an unprecedented ten-year period. Budget underspend was the main financial issue confronting Sure Start in its early years (Ball, 2005; Tunstill et al., 2005), but it faced several challenges associated with its area-based nature (Barnes, 2007). First, the majority of poor children lived outside disadvantaged areas (Tunstall and Lupton, 2003). Next, the governance and administration of such initiatives not only placed considerable burdens on local delivery partnerships when operating in an environment of highly centralised and directive policymaking, but also suffered from problems of representativeness and accountability (Cabinet Office, 2000). Finally, a look at the history of area-based UK and USA anti-poverty initiatives would have revealed only a minor impact (Alcock, 2005).

To fight child poverty, Bradshaw (2001), cited in Hendrick (2003: 211), contended that Labour should have pursued redistributive policies much more actively and early on. He went as far as to claim:

In fact, the first two years in office of this Government were dire for poor children. (Bradshaw, 2001: 10)

According to Hendrick (2003: 211), the primary reasons for any early lack of vigour in tackling child poverty can be traced back to New Labour's need to clearly differentiate itself from Old Labour's 'tax and spend' image. Working initially within the spending limits set by the Conservatives was part of that. Sutherland and Piachaud (2001) concluded that while there had been a reduction in British child poverty levels towards the end of Labour's first term, they remained high relative to other European nations, while Brewer et al. (2003) demonstrated that the statistically significant decline in child poverty levels might have been related to the choice of poverty line.

\section{Refocusing childcare, family support and child poverty strategies}

Towards the end of its first term in office, the New Labour Government was forced to confront the unintended consequences of the free market approach to its early 
childhood and child poverty programmes. As a consequence, the Treasury took on a more prominent childcare policy role, alongside its role as the lead department for poverty. The Inter-Departmental Childcare Review (Cabinet Office, 2002) heralded a significant early childhood policy reorientation early during the second Labour administration (2001-05), which culminated in the publication of the Ten Year Strategy for Childcare by HM Treasury itself (HM Treasury, 2004a). For an in-depth analysis of the changing role of HM Treasury in relation to early childhood policies in the first six years of Labour, including its emphasis on the volume of childcare and relative neglect of the issue of quality, see Cohen et al., (2004).

Even before the publication of the Childcare Review's recommendations, the Spending Review (HM Treasury, 2002) announced increased childcare budgets, as well as a more strategic and responsible role for local authorities. A closer relationship between education and employment was forged through the creation of the Interdepartmental Sure Start Unit, as the Department for Work and Pensions' programme of parental leave and family friendly employment policies dovetailed with the childcare and family support programme within the overarching framework of the strategies to help parents balance work and family life (Pugh, 2006).

Although the Childcare Review acknowledged that in the short term the market alone would not deliver the substantial increase in childcare places needed to support the Government's employment and poverty targets, especially in disadvantaged areas, it reiterated its longer-term vision of a childcare market, in which every parent could access affordable, good quality childcare. Hence it proposed only 'market failure' remedies for the interface problems between the childcare and poverty strategies. For instance, yet more supply-side, but only pump-priming, support to providers in the public, private for-profit and not-for-profit sectors.

An early decision had been taken to complement family support in the original Sure Start programmes, renamed Sure Start Local Programmes, with childcare provision for working parents (Tunstill et al., 2005). Alongside Neighbourhood Nurseries, Early Excellence Centres and other settings, they were transformed into less generously funded Children's Centres, one for every English community by 2010. Initially aimed at disadvantaged communities, they offered childcare, health and family support services for young children and their families and links to training and employment services, (Pugh, 2006). That childcare even in these settings should become self-sustaining remained axiomatic, although the likely financial viability of provision targeted at poor families, once supply-side subsidies were phased out, had already been seriously questioned (Harries et al., 2004).

Rolling out the National Extended Schools Programme alongside the Children's Centre initiative reinforced the distinction between targeted and universal provision. Extended Schools would offer school-based wrap-around and holiday childcare provision, study and parenting support in every primary and secondary school by 2010. But the challenges faced by these integrated programmes in going to scale have been documented in several reports (Cummings et al., 2006; NAO, 2006; Ofsted, 2006).

The vision for childcare articulated in 2002 was predicated on three factors: first creating employment opportunities for mothers - poor, lone and black and minority ethnic mothers in particular - second, persuading them to take these up and, third, consequently stimulating demand within the local childcare markets. Yet mounting evidence suggested that neither the routes towards achieving such conditions, nor their projected benefits, would prove obvious or straightforward (Brewer and Shaw, 2004; Brewer and Shepherd, 
2004; Kemp et al., 2004; Kazimirski et al., 2006). Even full employment might not guarantee the disappearance of child poverty and social exclusion (Gordon et al., 2000).

At the interface between childcare and family support strategies, a new agenda to improve developmental, educational, health and economic outcomes for all children and narrow the gap between the poor and better off, was announced in the 2003 Green Paper Every Child Matters, given legal force in the 2004 Children Act. This reform agenda for the delivery of children's services entailed both the improvement and integration of universal services, such as in early years' settings and schools, and the reconfiguration of family support services around children and families in one place, and delivered by multi-disciplinary teams, as in Childrens' Centres and Extended Schools (Pugh, 2006). Despite this becoming a major element of Labour's childcare policies, evidence of any direct impact on the uptake of childcare and family support, and resulting implications for child poverty levels, was scant, while the effectiveness of strategic partnerships remained in doubt (Percy-Smith, 2006).

Building on the Every Child Matters agenda, the refocused Ten Year Childcare Strategy formulated the next steps to achieve the original childcare strategy's objectives of affordability, choice, sustainability, flexibility and quality, which had all been found lacking in an impact assessment by the National Audit Office (2004).

Crucially, the Ten Year Strategy also reflected the findings from the Child Poverty Review (HM Treasury, 2004b) and an even more explicit convergence with the Government's child poverty strategy became apparent:

This strategy will not have succeeded if, along with its other achievements, it will not have helped more of this generation and the next out of poverty and worklessness. (HM Treasury, 2004a: 4)

On the cusp between New Labour's second and third term, it became clear, however, that this strategy, too, failed to address the needs of poorer families, such as large families, families with a disabled child or parent, and minority ethnic families (House of Commons Work and Pensions Select Committee, 2004; Dickens et al., 2005; Bell et al., 2005b; Kazimirski et al., 2006). Even in Sure Start Local Programmes, black and minority ethnic children were shown to be at a disadvantage (Craig et al., 2007).

The provision of childcare for the children of workless parents, or those working in the 'grey' economy, remained problematic (Dickens et al., 2005). Surprisingly, for middleclass parents, too, the childcare market was not operating according to the markets of economic theory (Ball and Vincent, 2005). A survey found over a third of parents paying for the supposedly free early education entitlement (Butt et al., 2007). Childcare not being free even within the new Children's Centres deterred families with the greatest needs from accessing their services (NAO, 2006; Ipsos-MORI, 2006).

The publication of interim findings from the 'National Evaluation of Sure Start' (Melhuish et al., 2005) proved a turning point. Reaching out to the poorest and most excluded families had been problematic, while there was also some evidence of adverse programme impacts on these children and their mothers. It had always been virtually impossible to reconcile its aims with those of other care and educational policies for young children (Clarke, 2006), while its very role in combating child poverty was questioned by Rutter (2006, 2007).

it is not in the least bit self-evident that a lack of employment or a lack of parental initiative led to the huge rise in child poverty that took place in the 1980s and early 1990 s... However 
worthwhile the Sure Start initiative, it seems implausible that child poverty could be dealt with satisfactorily without more radical changes in taxation and benefits. (Rutter, 2006: 139)

Emerging evidence of significant improvements in children's circumstances and parental employment in Sure Start areas (Barnes et al., 2006), of positive impacts on family functioning after several years (Belsky and Melhuish, 2007) and of the factors influencing variations in programme effectiveness (Anning et al., 2007) has only been partially taken into account in the development of the Children's Centre model.

Maternal employment rates, meanwhile, had remained almost static between 1994 and 2004 (ONS, 2005) undermining one of the main tenets of New Labour's welfare reform. Rising child poverty levels, however, posed perhaps the greatest challenge to realising the Ten Years Strategy's ambitions (Brewer et al., 2007; Shaw, 2007). As half of all children in poverty in the UK lived within working households (Palmer et al., 2007), increasing employment alongside childcare provision in disadvantaged areas could only be part of the answer. On a par with its economic and academic repercussions for children's life chances (Goodman and Sianesi, 2006; Feinstein et al., in press), the social costs of poverty for children warranted an urgent and multi-faceted response (Attree, 2007).

\section{Consequences of the mixed economy of childcare}

In Labour's third term the primary response to the problems identified above has been to interrogate the workings of the childcare and family support markets (Price Waterhouse Coopers, 2006a, 2006b), rather than to revisit the neo-liberal principles underlying welfare and public sector reforms and to question the very basis on which services for young children are provided.

The Government has reaffirmed its commitment to the mixed economy of childcare in the Childcare Act 2006. This introduces a requirement on Local Authorities to secure sufficient provision locally for employed parents, while themselves only acting only as 'provider of last resort'. From 2008 they have more discretion and flexibility to fund diverse local childcare markets, taking account of 'provider sustainability' (DfES, 2006). Both private for-profit and not-for-profit providers are expected to contribute to the delivery of childcare and family support services in Children's Centres and Extended Schools.

In the swiftly transforming childcare and family support service system in England, the private for-profit sector has assumed a dominant role. Market conditions have favoured the corporate childcare sector, which has grown sevenfold since 1997, after a good deal of consolidation (Penn, 2007: 202). In 2007, private for-profit providers, both corporate chains and sole traders or small partnerships, made up 78 per cent of the UK children's day nursery market, as compared with 11 per cent each supplied by the private not-for-profit and public sectors (Laing \& Buisson, 2007).

In such a market, pressure for deregulation is increasing, as evidenced by the Code of Practice introduced to address the issue of private providers charging parents 'top-up' fees for delivering the early education entitlement (DfES, 2006). Could the protection of providers become a significant policy driver in this not-so-free market? In contrast with the predictions of economic theory, two successive Ofsted overview reports have failed to produce evidence for major quality improvements, despite rising childcare costs (Ofsted, 2006, 2007).

In Australia, where childcare corporatisation has progressed apace, Sumsion (2006: 99) asks whether support for continued expansion of corporate childcare chains is 
ethically justifiable, while a secondary analysis of longitudinal US data has confirmed quality repercussions of provider status, with private for-profit chains scoring lowest overall (Sosinsky et al., 2007). According to a Canadian study (Cleveland et al., 2007), standards in not-for-profit and maintained provision are higher by about 15 per cent than in the for-profit sector, while in the UK several studies provide critical evidence of the very mixed performance on quality by the UK private for-profit childcare sector (La Valle et al., 2007; Mather et al., 2007).

The delivery of integrated early childhood education and care in the UK is bedevilled by the contrast between child-focused early education, which arguably is being treated as a 'public good', and childcare, which is regarded as a commodity to be purchased by parents. This 'sticky policy design', to use Rigby, Tarant and Neuman's (2007) description, coupled with New Labour's persistent belief in a market approach to social welfare provision, has affected all institutional arrangements in this area. Under these circumstances it is uncertain even whether the planned extension of the free early education entitlement for three- and four-year olds to 15 hours weekly by 2010 (Kazimirski et al., in press) will make much difference to accessibility.

Yet a policy approach that generously funds integrated early childhood education and care as a 'public good' does have a sound theoretical basis (Cleveland and Krashinksy, 2003). International evidence demonstrates that:

Without strong state investment and steering of this field, the result will be an insufficient supply of services for those who need them most, leading to increased numbers of children with special needs and learning difficulties; a lack of equity for poorer families; and overall poor quality of provision. (OECD, 2006: 256)

Among OECD member states, the UK is in a minority of liberal economies featuring a strong private market in this area, whereas compelling evidence exists that markets do not work effectively in all parts of the public sector (Greener, 2008). The de facto situation in other OECD member states supports the argument that predominant public funding has strong social and educational rationales (OECD, 2006).

\section{Conclusion}

Faced with this evidence, the question is warranted whether the impact of New Labour's child poverty strategy is being undermined by the free market approach informing childcare and family support strategies. The coupling of early childhood provision with parental employment status and its link to markets in integrated childcare and family support, appear particularly problematic at both a pragmatic and a principled level. Apart from the early education entitlement, access to quality childcare provision is not free for poor children in either of the two parallel early childhood provision systems currently operating here. Not only is this particular market inequitable, it is also inefficient and lacking in quality (Ball and Vincent, 2007).

In the light of the Treasury Committee's call to Government to intensify its efforts to meet its child poverty targets (House of Commons, 2007), addressing the interface problems between the Government's child poverty and national childcare strategies as part of this task would appear to make sense. The evidence presented here suggest that, as a first step, uncoupling the provision of childcare from parental employment status and extending a free entitlement significantly to children in their own right, might have 
beneficial impacts on the lives of young children growing up in poverty and counter social stratification.

Arguably, with Labour now in its third term, key issues concerning the social, moral and political status of children as social actors in their own right remain unresolved. For instance, relevant official documents remain ambivalent as to whether they or their parents are the consumers of childcare and family support provision. In addressing the position of children within its policies and reforms, any Government is faced with the need to balance the interests and views of parents, children and the state itself (Archard, 2003). The present analysis of the interface between Labour's childcare, family support and child poverty strategies suggests that so far this balance remains tipped in favour of the perceived needs of the state.

\section{Acknowledgements}

The author wishes to thank Helen Penn, Peter Moss, David Sloan and the anonymous reviewers of this article for their helpful comments.

\section{Notes}

1 Developments in England form the main focus of the present paper.

2 This paper adopts the Government definition of formal childcare that encompasses all forms of early education and childcare for children from birth to compulsory school age and out-of-school care for school age children, but not informal care by for example grandparents and other relatives.

3 Child poverty is defined as children living in households with less than 60 per cent of median household income, the Government's definition.

\section{References}

Alcock, P. (2005), "'Maximum feasible understanding" - lessons from previous wars on poverty', Social Policy and Society, 4, 3, 321-9.

Anning, A., Stuart, J., Nichols, M., Goldthorpe, J. and Morley, A. (2007), Understanding Variations in Effectiveness among Sure Start Local Programmes, SSU Research Report 024, London: DfES.

Archard, D.W. (2003), Children, Families and the State, Aldershot: Ashgate.

Attree, P. (2007), 'The social costs of child poverty: a systematic review of the qualitative evidence', Children and Society, 20, 1, 54-66.

Ball, M. (2005), Getting Sure Start Started, SSU Research Report 02, London: DfES.

Ball, S.J. and Vincent, C. (2005), 'The "Childcare Champion?" New Labour, social justice and the childcare market', British Educational Research Journal, 31, 5, 557-70.

Barnes, J. (2007), 'Targeting deprived areas: the nature of the Sure Start Local Programme Neighbourhoods', in J. Belsky, J. Barnes and E. Melhuish (eds), The National Evaluation of Sure Start-Does Area-based Early Intervention Work? Bristol: The Policy Press, pp. 25-44.

Barnes, J., Cheng, H., Howden, B., Frost, M., Harper, G., Dave, S. and Finn, J. (2006), Changes in the Characteristics of SSLP Areas between 2000/01 and 2003/04, SSU Research Report 016, London: DfES.

Bell, A., Finch, N., La Valle, I., Sainsbury, R. and Skinner, C. (2005a), A Question of Balance: Lone Parents, Childcare and Work, Research Report 230, London: Department for Education and Skills. 
Bell, A., Bryson, C., Barnes, M. and O'Shea, R. (2005b), Use of Childcare among Families from Minority Ethnic Backgrounds, SSU Research Report 011, London: DfES.

Belsky, J. and Melhuish, E. (2007), 'Impact of Sure Start Local Programmes on children and families', in J. Belsky, J. Barnes, and E. Melhuish (eds), The National Evaluation of Sure Start - Does Area-based Early Intervention Work? Bristol: The Policy Press, pp. 133-53.

Belsky J., Barnes J. and Melhuish E. (eds) (2007), The National Evaluation of Sure Start - Does Area-based Early Intervention Work? Bristol: The Policy Press.

Blair, T. (1999), 'Beveridge revisited: a welfare state for the twenty-first century', in R. Walker. (ed.), Ending Child Poverty-Popular Welfare for the 21st Century? Bristol: The Policy Press.

Bradshaw, J. (2001), 'Child poverty under Labour', in G. Fimister. (ed.), An End in Sight? Tackling Child Poverty in the UK, London: Child Poverty Action Group, pp. 9-27.

Bradshaw, J. and Mayhew, E. (eds) (2005), The Well-being of Children in the United Kingdom, London: Save the Children.

Brannen, J. and Moss, P. (eds) (2003), Rethinking Children's Care, Buckingham: Open University Press.

Brewer, M. and Shaw, J. (2004), Childcare Use and Mothers' Employment: A Review of British Data Sources, London: Department of Work and Pensions.

Brewer, M. and Shepherd, A. (2004), Has Labour Made Work Pay? DWP Working Paper 16, York: Joseph Rowntree Foundation, in association with Institute for Fiscal Studies.

Brewer, M., Clark, T. and Wakefield, M. (2002), 'Social security in the UK under New Labour: what did the Third Way mean for welfare reform?', Fiscal Studies, 23, 4, 505-38.

Brewer, M., Clark, T. and Goodman, A. (2003), 'What really happened to poverty in the UK under Labour's first term?', The Economic Journal, 113, 488, 240-57.

Brewer, M., Goodman, A., Muriel, A. and Sibieta, L. (2007), Poverty and Inequality in the UK: 2007, IFS Briefing Note 73, London: Institute for Fiscal Studies.

Butt, S., Goddard, K. and La Valle, I. with Hill, M. (2007), Childcare Nation? Progress on the Childcare Strategy and Priorities for the Future, London: Daycare Trust and National Centre for Social Research.

Cabinet Office (2000), Reaching Out: The Role of Central Government at Regional and Local Level, London: The Stationary Office.

Cabinet Office (2002), The Inter-Departmental Childcare Review: Delivering for Children and Families, London: The Strategy Unit.

Clarke, K. (2006), 'Childhood, parenting and early intervention: a crucial examination of the Sure Start programme', Critical Social Policy, 26, 4, 699-721.

Cleveland, G. and Krashinsky, M. (2003), Financing ECEC Services in OECD Countries, Paris: OECD.

Cleveland, G., Forer, B., Hyatt, D., Japel, C. and Krashinksy, M. (2007), 'An economic perspective on the future role of nonprofit early learning and childcare services in Canada', University of Toronto, http://www.childcarepolicy.net/ (accessed 14 November 2007).

Cohen, B., Moss, P., Petrie, P. and Wallace, J. (2004), A New Deal for Children? Re-forming Education and Care in England, Scotland and Sweden, Bristol: The Policy Press.

Craig, G., Adamson, S., Ali, N., Ali, S., Atkins, I., Dadze-Arthur, A., Elliott, C. and Murtuja, B. (2007), Sure Start and Black and Minority Ethnic Populations, SSU Research Report 020, London: DfES.

Cummings, C., Dyson, A., Papps, I., Pearson, D., Raffo, C., Tiplady, L. and Todd, L. (2006), Evaluation of the Full Service Extended Schools Initiative, Second Year: Thematic Papers, SSU Research Report 795, London: DfES.

Daniel, P. and Ivatts, J. (1998), Children and Social Policy, Basingstoke: Palgrave Macmillan.

DCSF (2007), The Children's Plan: Building Brighter Futures, London: The Stationary Office.

Dex, S. (2003), Families and Work in the Twenty-First Century, York: Joseph Rowntree Foundation in association with the Policy Press.

DfEE (1998), Meeting the Childcare Challenge, Green Paper, London: HMSO.

DfES (2001), Statistics of Education: Children's Daycare Facilities as at 31 March 2001, London: ONS. 
DfES (2006), 'Funding the free entitlement for 3 and 4 year olds', Letter from the Children's Minister to Local Authority Chief Executives and Directors of Children's Services, 7 December 2006 www.dfes.gov.uk/localauthorities/_documents/ (accessed 1 December 2007).

Dickens, S., Taylor, J. and La Valle, I. (2005), Local Childcare Markets: a Longitudinal Study, SSU Research Report 016, London: DfES.

Duffy, B. (2006), 'The curriculum from birth to six', in G. Pugh and B. Duffy. (eds), Contemporary Issues in the Early Years, 4th edn, London: Sage, pp. 79-92.

Duncan, A., Paull, G. and Taylor, J. (2001), Price and Quality in the UK Childcare Market, University of Nottingham Discussion Papers in Economics 01/13, Nottingham: University of Nottingham.

Esping-Andersen, G. (1990), The Three Worlds of Welfare Capitalism, Cambridge: Polity Press.

Esping-Andersen, G. (1999), Social Foundations of Postindustrial Economies, Oxford: Oxford University Press.

EU High Level Group (2004), 'Facing the challenge: the Lisbon Strategy for Growth and Development', Luxembourg, www.publications.eu.int (accessed 22 November 2007).

Feinstein, L., Duckworth, K. and Sabates, R. (2008), Education and the Family: Passing Success across the Generations, London: Routledge.

Ghate, D. and Hazell, N. (2002), Parenting in Poor Environments: Stress, Support and Coping, London: Jessica Kingsley Publishers.

Giddens, A. (1998), The Third Way, Cambridge: Polity.

Giddens, A. (2000), The Third Way and Its Critics, Cambridge: Polity.

Glass, N. (1999), 'Sure Start: the development of an early intervention programme for children in the UK', Children and Society, 13, 4, 257-64.

Goodman, A. and Sianesi, B. (2006), 'Early education and children's outcomes: how long do the impacts last?', Fiscal Studies, 26, 4, 513-48.

Gordon, D. and Pantazis, C. (1997), Breadline Britain in the 1990s, Aldershot: Ashgate.

Gordon, D., Adelman, L., Ashworth, K., Bradshaw, J., Levitas, R., Middleton, S., Pantazis, C., Patsios, D., Payne, S., Townsend, P. and Williams, J. (2000), Poverty and Social Exclusion in Britain, York: Joseph Rowntree Foundation.

Greener, I. (2008), 'Markets in the public sector: when do they work and what do we do when they don't?', Policy and Politics, 36, 1, 93-108.

Gregg, P. and Machin, S (2001), 'Childhood experiences, educational attainment and adult labour market performance', in K. Vleminckx and T.M. Smeeding. (eds), Child Well-Being, Child Poverty and Child Policy in Modern Nations, Bristol: The Policy Press, pp. 129-50.

Harker, L. (2006), Delivering on Child Poverty: What would it Take? London: Department for Work and Pensions.

Harries, T., La Valle, I. and Dickens, S. (2004), Childcare: How Local Markets Respond to National Initiatives, SSU Research Report 016, London: DfES.

Hay, C. (2005), 'Too important to leave to the economists? The political economy of welfare retrenchment', Social Policy and Society, 4, 2, 197-205.

Heckman, J. (2000), 'Policies to foster human capital', Research in Economics, 54, 1, 3-56.

Hendrick, H. (2003), Child Welfare - Historical Dimensions, Contemporary Debate, Bristol: The Policy Press.

HM Treasury (1999), The Modernization of Britain's Tax and Benefits System, Number 5: Supporting Children through the Tax and Benefits System, London: The Stationary Office.

HM Treasury (2001), Tackling Child Poverty: Giving Every Child the Best Possible Start in Life, London: The Stationary Office.

HM Treasury (2002), Opportunity and Security for All: Investing in an Enterprising and Fairer Britain - the Spending Review, London: The Stationary Office.

HM Treasury (2004a), Choice for Parents, the Best Start for Children: A Ten year Strategy for Childcare, London: The Stationary Office.

HM Treasury (2004b), The Child Poverty Review, London: The Stationary Office. 
Home Office (1998), Supporting Families, Green Paper, London: HMSO.

House of Commons Work and Pensions Select Committee (2004), Child Poverty in the UK, Volume I, London: The Stationary Office.

House of Commons Committee of Public Accounts (2007), Tax Credits, Twenty-Second Report of Session 2006-07, London: The Stationary Office.

House of Commons Treasury Committee (2007), The 2007 Comprehensive Spending Review, First Report of Session 2007-08, London: The Stationary Office.

Ipsos-MORI (2006), Children's Centres Value for Money Study: Perceptions of Parents and National Children's Charities, London: National Audit Office.

Kazimirski, A., Southwood, H. and Bryson, C. (2006), Childcare and Early Years Provision for Minority Ethnic Families, London: NatCen.

Kazimirski, A., Smith, R., Butt, S., Ireland, E. and Lloyd, E. (2008), Childcare and Early Years Survey 2007: Parents' Use, Views and Experiences, Research Report DCSF-RR025 London: DCSF.

Kemp, P., Bradshaw, J., Dornan, P., Finch, N. and Mayhew, E. (2004), Routes out of Poverty: A Research Review, York: Joseph Rowntree Foundation.

La Valle, I., Finch, S., Nove, A. and Lewin, C. (2000), Parents' Demand for Childcare, SSU Research Report 176, London: DfES.

La Valle, I., Arthur, S., Millward, C., Scott, J. with Clayden, M. (2002), Happy Families? Atypical Work and its Influence on Family Life, Bristol: The Policy Press in association with the Joseph Rowntree Foundation.

La Valle, I., Smith, R., Purdon, S., Bell, A., and Dearden, L., Shaw, J. and Sibieta, L. (2007), The Impact of Neighbourhood Nurseries on Families - The NNI Impact Study, SSU Research Report 020, London: DfES.

Laing \& Buisson (2007), Children's Nurseries UK Market Report 2007, London: Laing \& Buisson.

Latham, M. (2001), 'The Third Way: an outline', in GiddensA. (ed.), The Global Third Way, Cambridge: Polity Press, pp. 25-36.

Leseman, P. (2002), Early Childhood Education and Care for Children from Low-income or Minority Backgrounds, Paris: OECD.

Lewis, J. and Campbell, M. (2007), 'Work/family balance policies in the UK since 1997: a new departure?', Journal of Social Policy, 36, 3, 365-81.

Lloyd, E. (2000), 'Changing policy in early years provision and family support', in K. White. (ed.), The Changing Face of Childcare, NCVCCO Annual review Journal No. 2, London: NCVCCO, pp. 6580.

Lloyd, E. (2006), 'Children, poverty and social exclusion', in C. Pantazis, D. Gordon and R. Levitas. (eds), Poverty and Social Exclusion in Britain: The Millennium Survey, Bristol: The Policy Press, pp. 315-46.

Mather, S., Sylva, K. and Joshi, H. (2007), Quality of Childcare Settings in the Millennium Cohort Study, SSU Research Report 025, London: DfES.

Melhuish, E. (2004), 'A literature review of the impact of early years provision on young children', NAO, London, http://www.nao.org.uk/publications/nao_reports/ (accessed 22 November 2007).

Melhuish, E., Anning, A. and Hall, D. (2005), Early Impacts of Sure Start Local Programmes on Children and Families, SSU Research Report 013, London: DfES.

Middleton, S., Ashworth, K. and Braithwaite, I (1997), Small Fortunes: Spending on Children, Childhood Poverty and Parental Sacrifice, York: Joseph Rowntree Foundation.

Moss, P. (1999), 'Renewed hopes and lost opportunities: early childhood in the early years of the Labour Government', Cambridge Journal of Education, 29, 2, 229-38.

Moss, P. (2001), 'The UK at the crossroads: towards an early years European partnership', Facing the Future, Policy Paper 2, London: Daycare Trust.

Moss, P., Dillon, J. and Statham, J. (2000), 'The "child in need" or "the rich child": discourses, constructions and practice', Critical Social Policy 20, 2, 233-54.

Moss, P., Petrie, P., Cameron, C., Candappa, M., McQuail, S. and Mooney, A. (2003), Early Years and Childcare International Evidence Project, London: DfES. 
National Audit Office (NAO) (2004), Early years: Progress in Developing High Quality Childcare and Early Education Accessible to All, London: The Stationary Office.

National Audit Office (NAO) (2006), Sure Start Children's Centres, London: The Stationary Office.

OECD (2001), Starting Strong I, Paris: OECD.

OECD (2003), Babies and Bosses: Country Note UK, Paris: OECD.

OECD (2005), Babies and Bosses - Reconciling Work and Family Life, Volume 4, Paris: OECD.

OECD (2006), Starting Strong II, Paris: OECD.

Office for National Statistics (ONS) (2005), Labour Market Trends, July, London: ONS.

Ofsted (2006), Early Years, Safe and Sound, London: Office for Standards in Education.

Ofsted (2007), Early Years, Getting on Well, London: Office for Standards in Education.

Penn, H. (2007), 'Childcare market management: how the United Kingdom Government has reshaped its role in developing early childhood education and care', Contemporary Issues in Early Childhood, 8, 3, 192-207.

Penn, H, and Randall, V. (2005), 'Childcare policy and local partnerships under Labour', Journal of Social Policy, 34, 1, 79-97.

Penn, H., Burton, V., Lloyd, E., Mugford, M., Potter, S. and Sayeed, Z. (2006), 'What is known about the long-term economic impact of centre-based early childhood interventions?', Technical report in Research Evidence in Education Library, EPPI-Centre, Social Science Research Unit, Institute of Education, University of London.

Percy-Smith, J. (2006), 'What works in strategic partnerships for children: a research review', Children and Society, 20, 4, 313-23.

Piachaud, D. and Sutherland, H. (2001), 'Child poverty in Britain and the New Labour Government', Journal of Social Policy, 30, 1, 95-119.

Powell, M. (2007), 'The mixed economy of welfare and the social division of welfare', in M. Powell. (ed.), Understanding the Mixed Economy of Welfare, Bristol: The Policy Press, pp. 1-21.

PriceWaterhouseCoopers (2006a), The Childcare Market, London: PriceWaterhouseCoopers.

PriceWaterhouseCoopers (2006b), Overarching report on Children's Services Markets, London: PriceWaterhouseCoopers.

Pugh, G. (2006), 'The policy agenda for early childhood services', in G. Pugh and B. Duffy. (eds), Contemporary Issues in the Early Years, 4th edn, London: Sage, pp. 7-19.

Pugh, G. and Duffy, B. (eds) (2006), Contemporary Issues in the Early Years, 4th edn, London: Sage.

Rigby, E., Tarrant, K. and Neuman, M.J. (2007), 'Alternative policy designs and the socio-political construction of childcare', Contemporary Issues in Early Childhood, 8, 2, 98-108.

Rutter, M. (2006), 'Is Sure Start an effective preventive intervention?', Child and Adolescent Mental Health, $11,3,135-41$.

Rutter, M. (2007), Sure Start Local Programmes: an outsider's perspective', in J. Belsky, J. Barnes and E. Melhuish. (eds), The National Evaluation of Sure Start - Does Area-based Early Intervention Work? Bristol: The Policy Press, pp. 197-210.

Ruxton, S. and Bennett, F. (2001), Including children? Developing a Coherent Approach to Child Poverty and Social Exclusion across Europe, Brussels: Euronet.

Sefton, T. (2004), A Fair Share of Welfare: Public Spending on Children in England, CASE Report 25, London: Centre for Analysis of Social Exclusion with Save the Children.

Shaw, J. (2007), 'Eradicating child poverty', Economic Review, 24, 4.

Skinner, C. (2003), Running Around in Circles - Co-ordinating Childcare, Education and Work, York: Joseph Rowntree Foundation.

Skinner, C. (2006), How Can Childcare Help to End Child Poverty? Bristol: The Policy Press in association with the Joseph Rowntree Foundation.

Smith, T. (2007), 'Early years services in Britain 1997-2007: a quiet revolution?', Journal of Children's Services, 2, 2, 26-38.

Smith, T., Coxon, C. and Sigala, M. (2007), National Evaluation of the Neighbourhood Nurseries Initiative: Implementation Study, SSU Research Report 021, London: DfES. 
Solera, C. (2001), 'Income transfers and support for mothers' employment: the links to family poverty risks', in K. Vleminckx and T.M. Smeeding. (eds), Child Well-Being, Child Poverty and Child Policy in Modern Nations, Bristol: The Policy Press, pp. 459-84.

Sosinsky, L. S., Lord, H. and Zigler, E. (2007), 'For-profit/nonprofit differences in center-based child care quality: results from the National Institute of Child Health and Human Development Study of Early Child Care and Youth Development', Journal of Applied Developmental Psychology, 28, 5/6, 390410.

Stewart, J. (2007), 'The mixed economy of welfare in historical context', in M. Powell. (ed.), Understanding the Mixed Economy of Welfare, Bristol: The Policy Press, pp. 23-40.

Statham, J. and Mooney, A. (2003), Around the Clock: Childcare Services at Atypical Times, Bristol: The Policy Press in Association with the Joseph Rowntree Foundation.

Such, E. and Walker, R. (2005), 'Young citizens or policy objects? Children in the "Rights and Responsibilities" debate', Journal of Social Policy, 34, 1, 39-57.

Sumsion, J. (2006), 'The corporatization of Australian childcare: towards an ethical audit and research agenda', Journal of Early Childhood Research, 4, 2, 99-120.

Sutherland, H. (2002), One Parent Families, Poverty and labour Policy, London: National Council for One-Parent Families.

Sutherland, H. and Piachaud, D. (2001), 'Reducing child poverty in Britain: an assessment of Government policy 1997-2001', The Economic Journal, 111, 469, 85-101.

Sutherland, H., Sefton, T. and Piachaud, D. (2003), Poverty in Britain: The Impact of Government Policy since 1997, York: Joseph Rowntree Foundation.

Swank, D. (2005), 'Globalisation, domestic politics, and welfare state retrenchment in capitalist democracies', Social Policy and Society, 4, 2, 183-95.

Sylva, K., Melhuish, E., Sammons, P., Siraj-Blatchford, I. and Taggart, B. (2004), Effective Pre-school Education, Technical Paper 12, London: DfES/Institute of Education.

Tomlinson, S. (2001), Education in a Post-Welfare Society, Buckingham: Open University Press.

Tunstill, J., Meadows, P., Akhurst, S., Allnock, D., Chrysantou, J., Garbers, C. and Morley, A. (2005), Implementing Sure Start Local Programmes: An Integrated Overview of the First Four Years, SSU Research Report 10, London: DfES.

Tunstall, R. and Lupton, C. (2003), 'Is targeting deprived areas an effective means to reach poor people? An assessment of the rationale for area-based funding programmes', CASE Paper 70, Centre for Analysis of Social Exclusion, London School of Economics, London.

UN (1989), United Nations Convention on the Rights of the Child, New York: UN.

Vleminckx K. and Smeeding T.M. (eds) (2001), Child Well-Being, Child Poverty and Child Policy in Modern Nations, Bristol: The Policy Press.

Woodland, S., Miller, M. and Tipping, S. (2002), Repeat Study of Parents' Demand for Childcare, SSU Research Report 358, London: DfES. 